Vol. 2:1-8, December 2016

DOI: http://dx.doi.org/10.3126/jnarc.v2i0.16114

\title{
Production, Marketing and Value Chain Mapping of 'Srijana' Tomato Hybrid Seed in Nepal
}

\author{
Dinesh Babu Thapa Magar $^{1^{*}}$ and Devendra Gauchan ${ }^{2}$ \\ ${ }^{1}$ Socioeconomics \& Agricultural Research Policy Division, NARC, Khumaltar, Nepal \\ ${ }^{2}$ Bioversity International, Kathmandu, Nepal \\ *Correspondence: darlami.dinesh@gmail.com
}

Received 2015; Revised August 2016; Accepted October 2016

Scientific Editors: Yug Nath Ghimire, Dhruba Bhattarai

Copyright @ 2016 NARC. Permits unrestricted use, distribution, and reproduction in any medium, provided the original work is properly cited

\begin{abstract}
A tomato variety known as 'Srijana' developed by Nepal Agricultural Research Council (NARC) has been substantially popular among Nepalese farmers and entrepreneurs. To understand the seed value chain of the Srijana hybrid tomato, a survey was conducted in $2014 / 15$ with public research and extension institutions, private seed companies/firms, non-governmental organization and community group including individual farmers, involved in Srijana tomato seed production. The survey covered random selection of 30 agro-vets and 30 farmers in Kathmandu valley, Kavre, Nuwakot, Dolakha and Kaski districts, where production of Srijana tomato seed is mostly concentrated. A focus group discussion was also conducted with commercial tomato farmers in each of the study districts. The study showed a total production of 293 kg Srijana seed having a value of around 47 million Nepalese Rupees (NRs equivalent to US $\$ 470$ thousands) in year 2013/14. Private sector was the dominant actor sharing about $85 \%$ of the total Srijana seed production followed by non-governmental organization (10\%), farmers group $(3 \%)$ and governmental station/farm/centers $(2 \%)$, respectively. Out of the total Srijana seed produced, about $95 \%$ was consumed in domestic market, while 5\% was exported to India. The study revealed increasing trend of production, supply and price of Srijana tomato seed. Approximately 0.3 million NRs (US \$3,000) profit was estimated through the production of Srijana tomato seed in 0.05 hectares $\left(500 \mathrm{~m}^{2}\right)$ of land area. Agro-vets (private sector seed dealers) were the major actors receiving higher profit margins for supplying the seed from producers to farms. The farmers producing and selling the seed with technical assistance of public agencies received higher producer`s share (66.6\%) than farmers producing and selling seed through own group (60\%), technical assistance of non-governmental organization (53.3\%), and in contract with private seed companies $(26.7 \%)$. Majority of commercial tomato farmers had complaints on supply of poor quality seed in the market. As a result, there was declining faith on the quality of Srijana tomato seed. Limited access to parental lines and poor availability of skilled human resources were the key constraints to produce the quality Srijana seed. Therefore, it is recommended that there should be a provision of efficient quality control mechanisms, and development of human resources including public private partnerships for maintaining the genetic purity of parental lines and also improving the capacities of seed value chain actors for sustainable Srijana seed production in Nepal.
\end{abstract}

Keywords: Seed Marketing, Srijana Tomato Seed Actors, Srijana Tomato Seed Value Chain Map, quality Seed

\section{सारांश}

नेपाल कृषि अनुसन्धान परिषद मार्फत विकास गरिएको सिर्जना जातको गोलभेंडा नेपालका अधिकाशं कृषक तथा कृषि उद्यमीहरुका बीचमा अत्यन्त लोकप्रिय रही आएको छ। तसर्थ, सिर्जना गोलभेंडाको बीउको मूल्य श्रृंखला सम्बन्धि अध्ययन गर्ने उद्धेश्यले यसको बढ़ी मात्रामा बीउ उत्पादन हुने काठमाण्डौं, काभे, नुवाकोट, दोलखा र कास्की जिल्लामा बीउ उत्पादनमा संलग्न कृषक, सरकारी निकाय, निजी कम्पनी, गैर सरकारी संस्था र सामुदायिक संस्थाहरु लगायत ३० वटा एग्रोभेट तथा गोलभेंडा तरकारी उत्पादनमा संलग्न कृषकहरुसँग आर्थिक वर्ष २०१४/१५ मा अन्तरवार्ता तथा समूह लक्षित छलफल गरिएको थियो। यस अध्ययनको नतिजा अनुसार आर्थिक वर्ष २०१३/१४ मा सिर्जना गोलभेंडाको बीउ उत्पादनमा संलग्न सम्पूर्ण पात्रहरु मार्फत $\succ$ करोड ७० लाख नेपाली रुपियाँ बराबरको कूल २९३ किलोग्राम सिर्जना गोलभेंडाको बीउ उत्पादन गरिएको पाईयो। सिर्जना गोलभेंडाको बीउ उत्पादनमा संलग्न सम्पूर्ण पात्रहरुमध्ये निजी क्षेत्रले सिर्जना गोलभेंडाको कुल बीउ उत्पादनको करिब दर प्रतिशत हिस्सा ओगटेको पाईयो भनेस गैर सरकारी संस्था, कृषक समूह तथा सरकारी कृषि अनुसन्धान एवं फार्म केन्द्रहरु मार्फत ऋमश: करिब १० प्रतिशत, ३ प्रतिशत र २ प्रतिशत हिस्सा ओगटेको पाईयो। कुल उत्पादित सिर्जना गोलभेंडाको बीउ मध्ये करिब ९ू प्रतिशत बीउ स्वदेशमै खपत भएको पाईयो भने, करिब $y$ प्रतिशत बीउ भारतमा पानि मुख्य गरी गोरा बीउ कम्पनी मार्फत निकासी गरिएको पाईयो। यस अध्ययन मार्फत नेपालमा सिर्जना गोलभेंडा बीउको उत्पादन, आपूर्ति तथा बजार मूल्य वार्षिक रुपमा कमश: बढ़दै गईरहेको पाईयो। यस अध्ययनबाट सिर्जना गोलभेंडाको व्यवसायिक उत्पादन मार्फत प्रति रोपनी करिब ३ लाख नेपाली रुपियाँसम्म मुनाफा आर्जन गर्न सक्ने देखियो। सिर्जना गोलभेंडाको बीउलाई बीउ उत्पादन स्थलबाट गोलभेंडा तरकारी उत्पादन क्षेत्रसम्म पय्याउनमा एग्रोभेट तथा बीउ व्यवसायीहरुको भूमिका अहम रहेको पाईयो । जसले सो कार्य गर्दा निजी कम्पनी मार्फत संकलन गर्दा भन्दा गैरसरकारी संस्था तथा सरकारी निकायहरुको सहयोगमा कृषकहरुले उत्पादन गरेको बीउ सोकै संकलन एवं व्यवस्थापन गरी बेच्दा बढी मुनाफा लिएको पाईयो। बजार मूल्यमा कृषकको हिस्सा सबैभन्दा बढी (६६.६ प्रतिशत) सरकारी कार्यालयहरुको प्राविधिक सहयोगमा बीउ उत्पादन गर्ने कृषकहरुले प्राप्त गरेको पाईयो भने कृषक समूह मार्फत संगठित भएर बीउ उत्पादन गर्ने कृषकहरुले ६० प्रतिशत एवं गैरसरकारी कार्यालयहरुको प्राविधिक सहयोगमा तथा निजी बीड कम्पनीसँगको सम्कौता मुताविक बीउ उत्पादन गर्ने कृषकहरुले ऋमश: प३३.३ प्रतिशत र २६.७ प्रतिशत प्राप्त गरेको पाईयो । बजारमा गुणस्तरहिन सिर्जना गोलभेंडाको बीउको आपर्ति प्रति धेरैजसो कृषकहरुले गुनासोका साथै सो कारणले गर्दा उनीहरुको सिर्जना गोलभेंडा प्रविधि प्रतिको विश्वास पनि कमजोर हुँदै गईरहेको पाईयो । सिर्जना हाईत्रिड गोलभेंडा बीउ उत्पादनसँग सम्बन्धित मुख्य समस्याको रुपमा यसको उत्पादनका लागि आवश्यक भाले र पोथी बीउ प्राप्त गर्नमा बीउ उत्पादन गर्न ईच्छुक कृषकहरुको कमजोर पहुँच र दक्ष जनशक्तिको अभाव रहेको पाईयो। यसर्थ, नेपालमा सिर्जना गोलभेंडाको बीउको दिगो र गुणस्तरीय उत्पादनका लागि बीउको गुणस्तर अनुगमन तथा नियत्त्रण संयन्त्रका साथै दक्ष जनशक्तिको विकास र सरकारी एवं निजी क्षेत्र बीचको साकेदारीको सुदृढिकरण गरी सिर्जना हाईब्रिड गोलभेंडाको भाले र पोथीको आनुवंशिक शुद्धता कायम गर्नु एवं बीउ उत्पादनमा संलग्न पात्रहरुको सिर्जना गोलभेंडाको भाले र पोथी बीउमा सहज पहुँच एवं समुचित प्रयोगमा क्षमता अभिवृद्धि गरिनु आवश्यक छ।

\section{INTRODUCTION}

Seed is one of the major inputs of agriculture and means for dissemination of new technologies to farmers. Use of quality seeds of improved varieties is necessary to increase productivity and income of farmers (Gauchan et al 2014). Vegetable seed are one of the promising sub sectors for improving agricultural production, poverty reduction and food security (MoAD 2013, CEAPRED 2014). Vegetable seed are high-value and low-volume products and demand for improved and hybrid vegetable seeds are increasing every year due to increasing area under fresh vegetables production both for main season and off-season in Nepal (SCPL 2011). More than 60\% 
area of the commercial vegetable production pockets are under hybrid seeds with increasing trend due to their high yielding ability against open pollinated varieties (OPV) (MoAD 2013). However, hybrid seed production in Nepal is limited to only few crops, mainly tomato and maize, therefore, import of hybrid seed is increasing particularly in vegetables, rice and maize (MoAD 2013). The estimated vegetable seed demand for 2013/14 is 1,900 Metric Tons (mt) (SEAN 2013) while domestic seed production meets only half (53\%) of the total demand, the rest is fulfilled by import. National Seed Vision-2025 formulated by the Government of Nepal (GoN) has emphasised on self-sufficiency, import substitution and export promotion of quality seeds through domestic production for achieving increased seed replacement rate of vegetables from current $67 \%$ to $90 \%$, including development of 30 hybrids (20 from public sector and 10 from the private sector) in Nepal (MoAD 2013).

Tomato is the third most important vegetable after cauliflower and cabbage in terms of area, and production in Nepal. It is cultivated in about 20,000 hectares (ha) producing about 0.3 million MT tomatoes annually (MoAD 2014). Tomato is though best suited to tarai and mid hills, it is also becoming an attractive option for cash generation in the high hills (Pandey and Chaudhary 2004). Tomato is grown from subsistence to commercial scale; and from the east to far west and Terai to mid hill and mountain regions. Earlier, tomato was used to be grown only in the rainy season in the hills at subsistence level. However, the introduction of improved varieties has made it possible to grow tomato in the spring season as well (Ghimire et al 2001). Although a total of four varieties of tomato are released, and 28 varieties are registered, a large number of tomato variety seeds are available to farmers in Nepalese market due to open border and weak regulatory measures (MoAD 2013). The 'Srijana' is one of the popular varieties of tomato registered by National Seed Board with the effort of Nepal Agricultural Council (NARC) in 2010 (MoAD 2013, NARC 2014). Srijana tomato is mostly preferred by the farmers for its wider adaptability including its suitability for off seasonal production, superior taste, as well as tolerance to bacterial wilt disease. Srijana tomato is particularly recommended and popular among farmers for its farming inside the plastic house (Chapagain et al 2010, Pokharel and Thakur 2012). Thus, plastic house tomato production of this variety is gaining popularity among farmers (Chapagain et al 2010). The Srijana tomato variety has also been identified as one of the potential crop variety for import substitution and export promotion (MoAD 2013).

Presently, governmental and non-governmental actors have emerged and engaged in commercial seed production of the Srijana tomato in Nepal. The parental lines of Srijana tomato is maintained and produced by Horticulture Research Division (HRD), Khumaltar of NARC, and supplied to other actors for producing Srijana hybrid seed. However, there is a gap of information about the actors involved in Srijana tomato seed production, scales and practices of its production and marketing. Similarly, quality concerns on Srijana seed are increasingly raised by the stakeholders in different forums. The identification of the actors involved in Srijana tomato seed production and marketing including its quality issues and bottlenecks associated with its production might help in identifying intervention areas for further strengthening of Srijana tomato value chain. Hence, this study was carried out with the objectives of assessing production, marketing, economics and quality concerns of Srijana tomato seed in Nepal.

\section{MATERIALS AND METHODS}

This study applied both qualitative and quantitative research methods for obtaining information on Srijana tomato seed value chain. We identified actors obtaining parental lines of Srijana from the HRD, Khumaltar; as well as actors maintaining and using Srijana parental lines without concerning HRD (such as Gorkha Seed Company). Survey and interactions were made with all the identified actors involved in Srijana seed production. Value chain maps were developed to identify the actors involved and their functions in Srijana seed value chain. The study was done in Kathmandu valley, Kavre, Nuwakot, Dolakha and Kaski districts where production of Srijana seed was mostly concentrated. In addition, survey was also conducted with randomly selected 30 agro-vets involved in marketing of Srijana seed and 30 commercial tomato farmers (six farmers from one location) in those districts to understand the marketing practices and quality concerns of the variety. A focus group discussion was also conducted with the commercial tomato farmers in each of the selected district. A checklist and semi-structured interview schedule were used for collecting the primary data. Secondary data on Srijana tomato were also collected from the various published documents. Cost-benefit analysis of Srijana hybrid seed production, producer's share and marketing margin were analyzed through the collected data. Data analysis was carried out by using Microsoft Excel (MS-Excel) software.

\section{RESULTS AND DISCUSSION}

\section{Development, Maintenance and Supply of Parental Lines for Srijana Tomato Hybrid}

Srijana is the single hybrid variety of tomato so far developed by NARC through the cross between HRD-1 (female line) and HRD-17 (male line). Female line (HRD-1) is bacterial wilt resistant Hawaiian indeterminate type tomato line with round shaped small fruit size, while male line (HRD-17) is determinate type elite line obtained from The World Vegetable Center (AVRDC), Taiwan with oblong and large sized fruit (HRD 2006, DS Shrestha, personal communication, April 22, 2016 ). The research work on Srijana hybrid tomato development was started since 2005; when a total of 18 tomatoes inbred collected from various sources were evaluated and crossed in Horticulture Research Division of NARC (HRD 2006). From the series of evaluation of F1 crosses, HRD identified the F1 hybrid obtained from HRD-1 and HRD-17 cross superior in bacterial wilt resistant, yield and yield attributing characters and it was finally registered in the name of Srijana hybrid in 2010. HRD, Khumaltar of NARC is the main actor for maintaining and also supplying the Srijana parental lines to commercial Srijana seed producers and it supplied about $0.4 \mathrm{~kg}$ of parental lines to different seed producers in the year 2013/14 (HRD 2014). 


\section{Actors Involved in Srijana Tomato Seed Production}

A number of actors from the governmental, non-governmental and private sectors as well as a farmer's group were involved in production of Srijana hybrid seed in Nepal. The actors involved in Srijana seed production, and their mode of seed production in Nepal is given in Table 1.

Table 1. Srijana hybrid tomato seed producers in Nepal

\begin{tabular}{|l|l|l|l|}
\hline Name of the institution & Involvement since & Type of institutions & Mode of production \\
\hline Grokha Seed \& Agro Traders Company Limited Ktm & 2007 & Private & Own farm \\
\hline SEAN Seed Service Center Limited, Kathmandu & 2011 & Private & Own farm \& contracting farmers \\
\hline Kasthamandap Trade Point, Kathmandu & 2011 & Private & in contract with farmers \\
\hline $\begin{array}{l}\text { Agricultural Research Station, Malepatan, Kaski (seed } \\
\text { production in Kaski \& Syangja) }\end{array}$ & 2011 & Public & Own farm and through farmers \\
\hline $\begin{array}{l}\text { CEAPRED (seed production in Kavre, Parbat, Rukum, } \\
\text { Surkhet, Dailekh \& Baitadi) }\end{array}$ & 2011 & NGO & Farmers groups \& Cooperatives \\
\hline Sub-tropical Vegetable Production Centre, Rukum & 2012 & Public & Own farm \\
\hline ANAMOL Seed Company Private Limited, Kaski & 2013 & Private & Own farm \\
\hline Agro Shala Nepal, Kathmandu & 2014 & Private & Own farm \\
\hline Mero Agro Private Limited, Kathmandu & 2014 & Private & Own farm \\
\hline Puspanjali Seed Producer Group, Lalitpur & 2014 & Farmers group & Own farm \\
\hline
\end{tabular}

Majority of the actors involved in Srijana hybrid seed production belongs to private sector primarily producing seed either in their own farm only; or farmers' fields through contracts. Gorkha Seed Company, SEAN Seed Company, Anamol Seed Company, Agroshala Nepal, Mero Agro Pvt. Ltd. And Kasthamandap Trade Point was the key private actors involved in Srijana seed production (Table 1). An NGO, Center for Environmental and Agricultural Policy Research, Extension and Development (CEAPRED) also had involvement in Srijana hybrid tomato seed production and technical supports to some of its farmers/farmers groups and cooperatives located in various districts for the production and marketing of Srijana tomato seed. Among the public sectors, Agriculture Research Station (ARS), Malepatan of NARC and Sub-tropical Vegetable Production Centre (SVPC), Rukum of Department of Agriculture (DoA) were involved in Srijana seed production. ARS, Malepatan produced seed itself within the station and also trained the women farmers in Kaski and Syangja district for production and marketing of Srijana seed. A farmer`s group Puspanjali Seed Producer Group, Lalitpur in technical assistance of HRD, Khumaltar started Srijana tomato seed production since 2014.

\section{Production Trend of Srijana Tomato Seed}

Our data revealed an increasing trend of Srijana hybrid tomato seed production in the last 7 years (Figure 1). Although Srijana hybrid was formally registered in 2010, technology testing and seed production activities were initiated by HRD Khumaltar since 2005 with technical supports and parental lines to beneficiary farmers (eight women farmers) in Syangja and Kavre and successfully produced small quantity of seed in 2007 (Nepal SIMI 2007). Similarly, Gorkha Seed Company started commercial production of Srijana seed since 2007/08. With the formal registration of Srijana hybrid tomato, other actors also gradually emerged and started commercial seed production after formal agreement with HRD, Khumaltar. In 2007, only about $0.24 \mathrm{~kg}$ of Srijana hybrid seed was produced and supplied in the market, but the production and marketing increased to $293 \mathrm{~kg}$ in 2013/14 equivalent to about 47 million Nepalese Rupees (NRs) revenue generation.

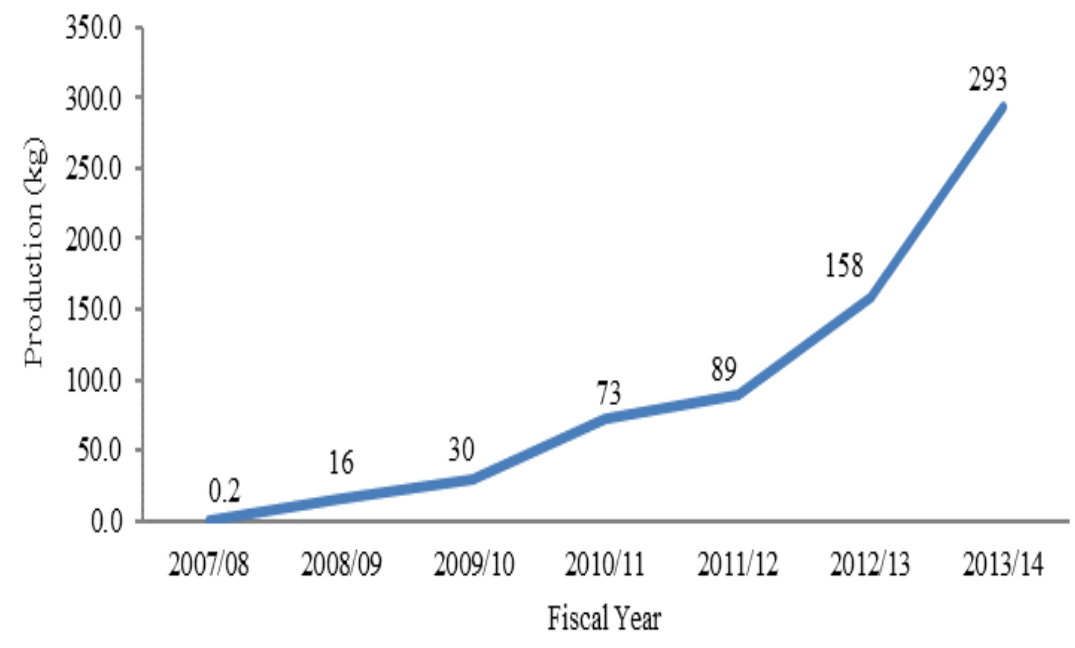

Figure 1. Trend of Srijana hybrid tomato seed production in Nepal. 
Vol. 2:1-8, December 2016

DOI: http://dx.doi.org/10.3126/jnarc.v2i0.16114

\section{Share of Actors in Srijana Hybrid Seed Production}

Among the various actors involved in Srijana seed production, Gorkha seed company was the major actor producing more than half $(55 \%)$ of the total seed produced in the country in the year 2013/14 (Figure 2). Other actors such as SEAN Seed Company, CEAPRED, and Anamol Seed Company shared about 19\%, 10\%, and 5\% of the total seed production, respectively. While Agroshala Nepal, Mero Agro Limited, and Puspanjali seed producer group each shared about 3\% of the total seed production. ARS, Malepatan shared about 1\% while Kasthamandap Trade Point and one of the public farms Sub-tropical Vegetable Production Centre (SVPC), Rukum each shared less than $1 \%$ of the total Srijana seed production.

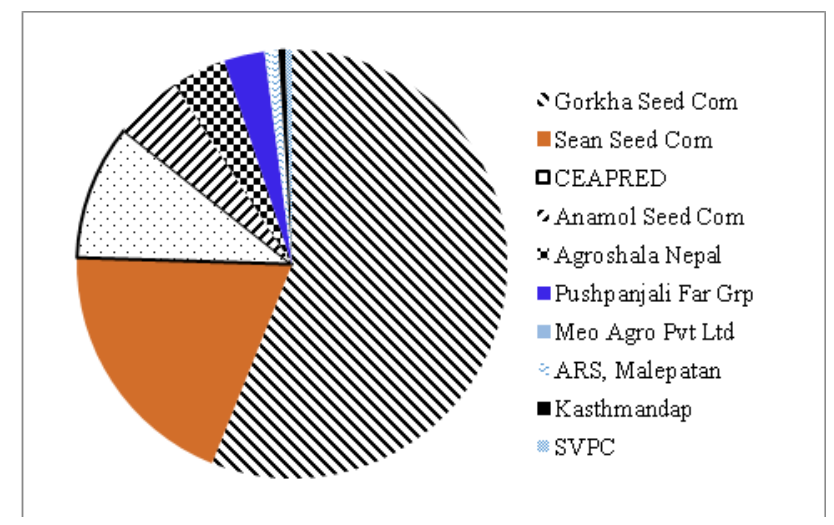

Figure 2. Share of actors in Srijana hybrid tomato seed production in Nepal.

Gorkha seed company, a dominant actor for Srijana seed production and marketing has recently introduced and promoted Samjhana and Sarita hybrid varieties of tomato exclusively in the market. With its increased focus on promotion of these new varieties, it's share on Srijana tomato seed production is more likely to decline considerably in the future and the total production of Shrijana seed also may go down unless other actors increase their volume of Srjana seed production or get involved in its seed production.

\section{Price Trend of Srijana Hybrid Tomato Seed in Nepal}

Srijana tomato seed had the highest price among the vegetables formally developed and registered in Nepal. The study revealed a gradual increase in the price of Srijana tomato seed over the years. During the initial year of Srijana seed production (FY 2007/08), the price per kilogram $(\mathrm{kg})$ was around $80,000 \mathrm{NRs}$, which gradually increased over the years and reached to NRs. 160,000/kg in FY 2013/14 (Figure 3). There was varying price for Srijana seed for different seed producers in the market. The retailing price for Srijana seed produced and supplied by Gorkha Seed company was the highest (NRs. 175,000/kg) followed by Agroshala seed company (NRs. 165,000/kg), and Anamol seed company (NRs. 162500/kg), respectively. There was similar price (NRs. 150,000/kg) for Srijana seed produced and supplied by SEAN Seed Company, Mero Agro Limited, Kasthamandap Trade Point and other seed dealers who marketed the seed obtained through farmers assisted by governmental and non-governmental organizations.

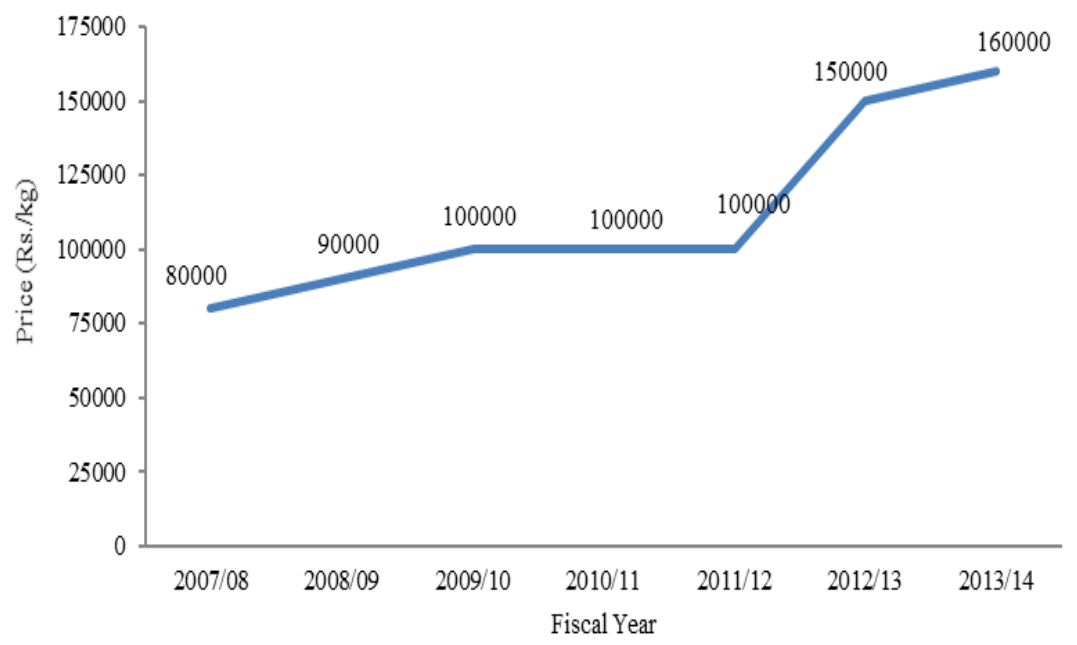

Figure 3. Trend of price (Rs./kg) of Srijana hybrid tomato seed in Nepal. 


\section{Value Chain Map, Marketing Practice, and Marketing Margin of Srijana Tomato Seed}

Several actors were involved in the seed value chain of Srijana tomato. The major actors involved in seed value chain of Srijana tomato include public agencies, private seed companies/dealers/suppliers, NGOs and farmers groups and the individual farmers who perform various functions such as input supply, production, processing, collection, wholesaling and retailing of the Srijana seed (Figure 4).

Input supply: Parental lines including technical training services and other inputs such as fertilizer, irrigation and tools/equipments are essential for the production of Srijana tomato. HRD, Khumaltar being a public and mother organization for developing Srijana tomato technology holds an ownership and authority to provide inputs such as Srijana parental lines and technical trainings to the Srijana seed producers. HRD had developed Memorandum of Understanding (MoU) and supplied parental lines to all the Srijana seed producers and also provided technical backstopping to the seed producers except Gorkha Seed Company (Table 2). There was a linkage and coordination gap between HRD and Gorkha Seed Company. Gorkha Seed Company was found to be maintaining the parental lines of Srijana tomato itself and using them for the seed production although it is legally questionable. Public agencies and NGOs also provided technical trainings and parental lines obtained through HRD to their seed producer farmers.

Table 2. Production and supply of Srijana parental lines from HRD, Khumaltar in last three years

\begin{tabular}{|l|l|l|}
\hline Fiscal year & $\begin{array}{l}\text { Total quantity of parental lines provided to } \\
\text { seed producers (kg) }\end{array}$ & $\begin{array}{l}\text { Number of actors obtaining } \\
\text { parental lines from HRD }\end{array}$ \\
\hline 2014 & 0.394 & 8 \\
\hline 2013 & 0.230 & 6 \\
\hline 2012 & 0.059 & 4 \\
\hline
\end{tabular}

Source: HRD 2014, HRD 2013, HRD 2012

Production and Processing: Public agencies (research stations and firms), private seed companies, non-governmental organizations, and farmers/farmers groups were the major actors involved in Srijana tomato seed production. Overall, private sector was the dominant actor having the largest share $(85.2 \%)$ in Srijana seed production followed by NGO (10.4\%), farmers group (3.1\%) and governmental station/farms $(1.4 \%)$, respectively. There was a practice of processing the seed manually by all the seed producers.

Collection and Packaging: After processing, private sectors often had a practice of doing seed testing, truthful labeling and packaging activities by themselves and then the seed was supplied to wholesaling agro-vets, and retailing agro-vets and ultimately to the tomato vegetable growing farmers. While there were a number of emerging private firms (Pokhara Seed Company, NEMACOL, Live Seed) and agro-vets who had a practice of collecting the seed produced by the farmers associated with governmental research station/farm and NGOs and selling it in the market after testing, packaging and labeling.

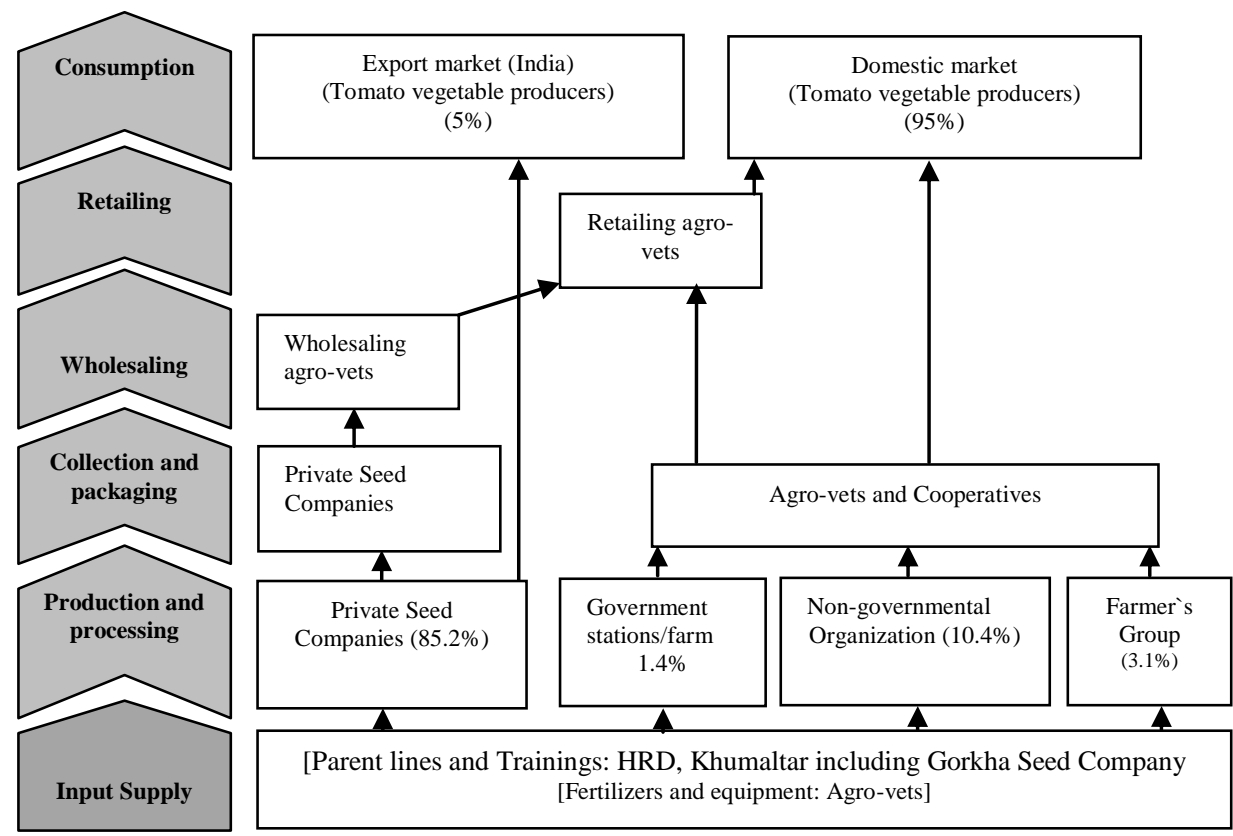

Figure 4. Value chain map of Srijana hybrid tomato seed. 
Wholesaling, retailing, and marketing margins: Seed produced by private seed companies were mostly supplied in the market through the wholesaling agro-vets while retailers (agro-vets, seed dealers) supplied the seed produced by other actors in the market. About $95 \%$ of the total seed produced in Nepal in FY 2013/14, was consumed within the country, while about 5\% was exported to India. Gorkha Seed Company was the only one actor to export a part of its seed to India (Sikkim) and insisted that they have a growing demand for Srijana tomato seed even in the international market.

Marketing margin is the difference between the value of a product or group of products at one stage in the marketing process and the value of an equivalent product or group of products at another stage. Due to the presence of a fairly good number of seed producers of Srijana tomato, agro-vets had an opportunity to choose the seed supplier and generate higher profit margins (Table 2). Based on the mode of seed collection/purchase, agro-vets/seed dealers obtained varying margins during marketing of Srijana tomato seed. The study revealed a marketing margin of about $17 \%$ to $25 \%$ taken by the agro-vets from selling of Srijana tomato seed collected from Private seed companies and the margin to them was higher (upto 56\%) while collecting, packaging and selling the seed directly from farmers group or farmers assisted through public agencies and NGO (Table 3).

Table 3. Marketing margin for the actors involved in marketing of Srijana tomato seed

\begin{tabular}{|c|c|c|c|c|}
\hline $\begin{array}{l}\text { Actors producing Srijana tomato } \\
\text { seed }\end{array}$ & $\begin{array}{l}\text { Purchasing price of } \\
\text { Srijana seed of different } \\
\text { seed companies paid by } \\
\text { the seed dealers } \\
(\mathrm{NRs} . / \mathrm{kg})(\mathrm{A})\end{array}$ & $\begin{array}{l}\text { Estimated marketing cost } \\
\text { (transportation, cleaning, } \\
\text { packaging) to the seed } \\
\text { dealers (NRs./kg) } \\
\text { (B) }\end{array}$ & $\begin{array}{l}\text { Selling price of } \\
\text { Srijana seed by } \\
\text { the seed dealers } \\
\text { (NRs./kg) } \\
\text { (C) }\end{array}$ & $\begin{array}{l}\text { Marketing margin } \\
\text { of the seed dealers } \\
(\mathrm{NRs} . / \mathrm{kg}) \\
(\mathrm{C})-(\mathrm{A}+\mathrm{B})\end{array}$ \\
\hline Gorkha Seed company & $1,50,000$ & 0 & $1,75,000$ & $25,000(17 \%)$ \\
\hline Anamol Seed company & $1,30,000$ & 0 & $1,62,500$ & $32,500(25 \%)$ \\
\hline SEAN Seed company & $1,20,000$ & 0 & $1,50,000$ & $30,000(25 \%)$ \\
\hline Agroshala Company & $1,40,000$ & 0 & $1,65,000$ & $25,000(18 \%)$ \\
\hline Farmers assisted by CEAPRED & 80,000 & 15,000 & $1,40,000$ & $62,000(56 \%)$ \\
\hline $\begin{array}{l}\text { (Governmental stations (ARS and } \\
\text { SVPC)/farmers assisted by them }\end{array}$ & $1,00,000$ & 15,000 & $1,50,000$ & $35,000(35 \%)$ \\
\hline Puspanjali Farmers Group & 90,000 & 15,000 & $1,50,000$ & $52,000(50 \%)$ \\
\hline
\end{tabular}

Note: Figure in parenthesis indicates percent share of marketing margin.

\section{Farmer`s or Producer`s Share in Retail Price of Srijana Seed}

Farmers share is the ratio of farm gate price to retail price of any product or commodity. It provides an important message on the gap between producer price and price paid by the consumers and can also be expressed as,

Farmer`s or Producer`s Share $(\%)=($ Farm-gate price/ Retail price) $x 100$

The study revealed a variation in the price received by the farmers for Srijana seed based on their mode of production and sale. The farmers producing seed with technical assistance of governmental organization obtained the higher price (NRs. 100,000/kg) followed by farmers producing seed in technical support of NGO (NRs. 800,00/kg) and in contractual arrangement with private seed company (SEAN seed) (NRs. 400,00/kg), respectively. Governmental and non-governmental organizations provided market linkage support to their seed producer farmers/groups and the buyers usually offered a higher price to the farmers/groups producing seed in technical assistance of such organizations as they had a higher trust on quality of such seed. Farmer`s share was found higher (66.6\%) for Srijana seed produced by the farmers in technical assistance with governmental stations followed by farmers selling seed through own groups $(60 \%)$, farmers assisted by NGO (53.3\%) and contracted with the private seed companies (26.7\%), respectively. There was a huge gap between the price received by the producers and price paid by the consumers (seed users) particularly for the farmers associated with the private seed company. Private seed companies had higher tendencies of making higher profit at the expense of farmers and paying unfairly to their contracted farmers for seed production. Majority of the seed producing farmers were also not satisfied with the price received from such seed company and such an unfair profit distribution is likely to effect on the sustainability of Srijana seed business.

\section{Economics of Srijana Tomato Seed Production}

Srijana seed was produced by different actors with different management practices. There was varying management options such as size of plastic tunnel, use of inputs, and intercultural operations practices by different actors across the locations. This study generated information on economics of Srijana seed production based on the cost and benefits associated with Srijana seed production in a plastic tunnel $\left(12 \mathrm{~m} \times 5 \mathrm{~m}=60 \mathrm{~m}^{2}\right)$ in farmers field of Kavre district (Table 4). While calculating benefit cost of the Srijana seed production, cost for the durable items such as plastic for tunnel preparation and other materials have been calculated taking their depreciation value (considering their expected life of 4 years).

Srijana tomato hybrid seed production is though a painstaking job, the study revealed it as one of the important option for employment and income generation to the farmers. More importantly, it was the women who were mostly involved in Srijana tomato seed production and their involvement in production and marketing practices of Srijana seed was also helpful for their socio-economic empowerment. While producing Srijana tomato seed, $81 \%$ of the total cost was incurred in labor followed by tools/equipment (11\%) and inputs (8\%), respectively. It is estimated that an employment for 80 labor days is generated for producing about $1 \mathrm{~kg}$ of Srijana tomato seed. It is estimated that farmers can generate an income of about 0.3million NRs (US\$ 3,000) from one ropani (about $500 \mathrm{~m}^{2}$ ) of land area. The average production of seed in a plastic tunnel $(12 * 5$ square meters) is about one kilogram. 
Table 4. Economics of Srijana tomato seed production in a plastic tunnel $\left(12 \mathrm{~m} \times 5 \mathrm{~m}=60 \mathrm{~m}^{2}\right)$

\begin{tabular}{ll}
\hline Particulars & Amount (NRs.) \\
\hline Input cost: seed (parent lines), chemical fertilizers, & 3,395 \\
$\begin{array}{l}\text { FYM/Compost, Micronutrients and pesticides } \\
\text { Labour cost: tunnel and field preparation, intercultural } \\
\text { operations, crossing activities, harvesting, seed extraction, } \\
\text { cleaning, drying, packaging and marketing }\end{array}$ & \\
Tools/equipment cost (after depreciation): plastics, bamboo & 32,800 \\
poles/sticks, jute ropes, irrigation tank and pipes, sprayer, & 4,450 \\
forceps, scissors, petridish & \\
Total cost & 40,645 \\
Average production of seed & $1 \mathrm{~kg}$ \\
Price per kg of seed & 80,000 \\
Net profit from seed production & 39,355 \\
Benefit-cost ratio & 1.96 \\
\hline
\end{tabular}

\section{Quality Constraints Associated with Production of Srijana Tomato Hybrid Seed}

Srijana is one of the most popular varieties of tomato among the farmers in Nepal. The demand and supply of the seed of this variety is increasing gradually; however, majority of the farmers showed their concern on supply of poor quality Srijana seed in market resulting into economic loss and their declining trust on Srijana variety seed. There was involvement of wide range of actors in Srijana seed enterprise with varying skills, knowledge and capacity. In such circumstances, it seems complex to manage the quality seed production unless the quality control mechanisms are effective. The present quality control mechanisms and regulations such as field inspections, seed testing, and seed certifications from the public sector are known to be very poor and less effective. Moreover, the seed producers do not have easy access to seed testing services particularly in the hill and mountain regions. The seed certification and quality assurance practice from formal sector agencies is also poorly adopted for vegetable seeds. Similarly, there is also very limited capacity building and other support activities to Srijana seed actors by the public sector. Such conditions provide space for production and supply of poor quality seed and that eventually effects on trust of farmers towards the technology or Srijana variety. Therefore, it is very necessary to take initiatives and measures (such as field inspection, seed testing and certification, public-private-community linkages or partnerships, monitoring and capacity building of the seed producers and suppliers) to enhance the quantity and quality of Srijana seed production. The seed producing actors are facing the problems of limited access to the parental lines including poor availability of skilled human resource for crossing of parental lines, and increasing incidence of diseases hindering quality production of Srijana seed. The HRD, Khumaltar supply parental lines only to publically recognized organizations such as private seed companies or NGOs. Srijana parental lines are not supplied to every individual farmer interested in its seed production and other informal organizations. Such policy of the public agencies has prevented the access of many interested farmers to the parental lines for commercial Srijana tomato seed production. Therefore, apart from ensuring seed quality control mechanisms and capacity building activities, it is necessary to develop regulatory measures to enable easy access and availability of Srijana parental lines for assuring the sustainable and efficient production and supply of Srijana hybrid tomato seed.

\section{CONCLUSIONS AND RECOMMENDATIONS}

Tomato is one of the top vegetables grown in Nepal. To support the increased production and productivity of tomato in the country, NARC has developed Srijana tomato hybrid, which embraces various attributes that are increasingly preferred by the farmers and is increasingly becoming popular among the farmers and entrepreneurs. The present study revealed an increasing production, supply and price of Srijana seed over the years. Farmers and entrepreneurs involved in production and marketing of Srijana seed also received high price and profit margins from Srijana hybrid seeds. Although, several actors were involved in Srijana seed production, private sector had the largest share in Srijana hybrid seed production and marketing. The increased production and supply of Srijana tomato seed has undoubtedly contributed in increasing employment and income generation and import substitution of the tomato hybrids. However, due to poor quality control measures, concerns on quality of Srijana seed are increasing. On the other hand, poor access and availability of the parental lines, limited skilled human resources and limited support from the public agencies to the hybrid seed producers are limiting the production of quality Srijana hybrid seed in its full potential. Therefore, it is very necessary to strengthen seed quality control mechanisms and developing human resources for assuring quality production of Srijana hybrid tomato seed. One of the options would be to develop mechanism by public sector research and development (R \& D) agencies for increased production and genetic purity maintenance of the parental lines, regular monitoring of hybrid seed production and marketing assuring quality testing services in rural hills and remote locations. Similarly, strengthening linkage and partnership among public and private agencies including farmers is also vital for enabling easy access and quality use of parental lines by the seed producers and assuring sustainable hybrid seed production and supply in Nepal.

\section{ACKNOWLEDGEMENT}

We are thankful to Dr KP Paudel and Dr SL Shrestha of Horticulture Research Division for their valuable suggestions and guidance to accomplish this project. Special thanks goes to all men and women seed producing farmers, members of the farmers groups and cooperatives, seed entrepreneurs (Seed dealers/Agrovets, seed company officials), governmental research stations and farms including DADOs, CEAPRED officials and other stakeholders of survey districts, who provided their valuable information, insights and support for this study. 
Vol. 2:1-8, December 2016

DOI: http://dx.doi.org/10.3126/jnarc.v2i0.16114

\section{REFERENCES}

CEAPRED. 2014. Internal assessment for vegetable seed project (VSP) III. Center for Environmental and Agricultural Policy Research, Extension, and Development, Kathmandu.

Chapagain TR., BB Khatri, and JL Mandal. 2011. Performance of tomato varieties during rainy season under plastic house conditions. Nepal Journal of Science and Technology 12. pp.17-22.

Chapagain TR., S Piya, JL Mandal and BP Chaudhary. 2010. Up-scaling of polyhouse tomato production technology in mid and high hills of eastern Nepal. In: (MN Paudel, TP Barakoti and YN Ghimire, eds). Proc. $9^{\text {th }}$ National Outreach Research Workshop, 7-8 June 2010, Kathmandu. pp.116-120.

Gauchan D., DB Thapa Magar, S Gautam, S Singh and US Singh. 2014. Strengthening seed system for rice seed production and supply in Nepal. IRRI-NARC collaborative EC-IFAD funded project on Seed Net Development. Socioeconomics and Agricultural Research Policy Division, Nepal Agricultural Research Council, Nepal. 40p.

Ghimire SR., PP Subedi and SK Green. 2000. Status of tomato yellow leaf curl virus in tomato in the western hills of Nepal. Nepal Agriculture Research Journal 4-5,1-4.

HRD. 2006. Annual report 2005/06. Nepal Agricultural Research Council, Horticulture Research Division, Khumaltar, Lalitpur.

HRD. 2012. Annual Report 2011/12. Nepal Agricultural Research Council, Horticulture Research Division, Khumaltar, Lalitpur.

HRD. 2013. Annual Report 2012/13. Nepal Agricultural Research Council, Horticulture Research Division, Khumaltar, Lalitpur.

HRD. 2014. Annual Report 2013/14. Nepal Agricultural Research Council, Horticulture Research Division, Khumaltar, Lalitpur.

MoAD. 2013. National seed vision 2013-2025 (seed sector development strategy). Government of Nepal, Ministry of Agricultural Development (MoAD), National Seed Board, Seed Quality Control Centre, Harihar Bhawan, Lalitpur, Nepal.

MoAD. 2014. Statistical information on Nepalese agriculture (2013/14). Government of Nepal, Ministry of Agricultural Development (MoAD), Agri-Business Promotion and Statistics Division, Statistics Section, Singha Durbar, Kathmandu, Nepal.

NARC. 2014. Released and registered crop varieties in Nepal (1960-2013). Nepal Agricultural Research Council, Communication, Publication and Documentation Division, Khumaltar, Lalitpur.

Nepal SIMI. 2007. Nepal SIMI annual performance report. Nepal SIMI Report No. 17. The Nepal Smallholder Irrigation Market Initiative (Nepal SIMI), WINROCK/IDE/CEAPRED/SAPPROS/AEC/ANSAB, 2007.

Pandey, YR and BN Chaudhary. 2004. Evaluation of tomato varieties and their planting dates for commercial production under Jumla agroecological condition. In: (BB Khatri, BP Sharma, PP Khatiwada, KP Paudyal, BR Khadge and HN Regmi, eds). Proc. $4^{\text {th }}$ National Horticultural Research Workshop, 2-4 March 200, Kathmandu. pp.380-385.

Pokharel, TR and MK Thakur. 2012. Evaluation of promising cultivars of tomato for off-season production in midhills of Nepal and its promotion to hill farmers. In: Agriculture research for development (MN Paudel and B Kafle, eds). Proc. $10^{\text {th }}$ National Outreach Workshop, 27-28 February 2012, RARS, Lumle, Kaski. pp.200-203.

SCPL. 2011. A report on vegetable value chain analysis of vegetable seed in Nepal. Solutions Consultant Private Limited, Kathmadnu, Nepal.

SEAN. 2013. Market information study for analyzing national demand, supply, import and export situation of vegetable seeds in Nepal. Seed Entrepreneur's Association, Nepal. 